\title{
Avtorizirani prepis partiture Beethovnove Šste simfonije v F-duru, opus 68
}

\begin{abstract}
A
vtorizirani prepis partiture Beethovnove $\check{S}$ este simfonije v F-duru, op. 68, je eden od zakladov Narodne in univerzitetne knjižnice v Ljubljani. Odkar ga hrani, zbirke pa so ga preučevali in občudovali eminentni raziskovalci in poustvarjalci, poznavalci Beethovnovega dela, kot tudi drugi zainteresirani obiskovalci. ${ }^{1}$ Poti rokopisa pred ustalitvijo v NUK pa so nejasnejše in skrivnostnejše. Nekatere v preteklosti izrečene domneve v zvezi z njegovo provenienco so danes pojasnjene, druge opuščene, najbolj izzivajoče pa še čakajo na faktum, ki ga morda še premorejo zastrti na široko razpršeni pisni viri. Partitura je bila prepisana iz Beethovnovega avtografa v zadnji četrtini leta $18 \circ 8$ in je služila za prvo javno izvedbo simfonije na Dunaju 22. decembra I808. ${ }^{2}$ Prepisal jo je poklicni kopist Joseph
\end{abstract}

I Ob 20o-letnici Beethovnovega rojstva je Glasbeni oddelek NUK pripravil Beethovnovo razstavo. Med drugim so razstavili prvotiske, izdane za časa skladateljevega življenja, najstarejše koncertne sporede z izvedbami Beethovnovih skladb ter gradivo v zvezi z izvolitvijo Beethovna za častnega člana ljubljanske Filharmonične družbe.

2 Jens Dufner, »Kritischer Bericht, « v Beethoven Werke, Abt. I, Bd. 3, Symphonien III, ur. Jens Dufner (München: G. Henle, 2013b), 277.
Klumpar, s katerim je Beethoven sodeloval med letoma 1805 in $1808 .^{3}$ Skladatelj je partituri dopisal naslov, dodal več navodil za igranje ter popravil nekaj not.

Partituro je leta I862 iz arhiva ljubljanske Filharmonične družbe potegnil njen kronist Friedrich Keesbacher (I83I-190I) ter v zgodovinskem pregledu delovanja društva, objavljenem v prilogi ljubljanskega časnika Laibacher Zeitung, javnost prvič opozoril nanjo. ${ }^{4}$ Keesbacher, po poklicu zdravnik, se je naselil v Ljubljani le leto pred tem, zato se je pri zbiranju podatkov opiral na pripovedovanje sodobnikov in društveni arhiv. Ob pregledovanju dokumentov je naletel na že po-

3 Alan Tyson, »Notes on Five of Beethoven's Copyist, « Journal of the Ameri can Musicological Society 23, št. 3 (1970): 456-60; Sieghard Brandenburg, ur. Ludwig van Beethoven - Briefwechsel Gesamtausgabe, I (München: G. Henle Verlag, 1996-1998), 327-8; Jens Dufner, »Schreibdialoge. Beethoven und sein Kopist Joseph Klumpar, « v Bonner Beethoven-Studien, Band II, uredili Bernhard R. Appel, Joanna Cobb Biermann in Julia Ronge (Bonn: Beethoven-Haus Bonn, Carus, 2014), 68.

4 Friedrich Keesbacher, $\gg$ Die philharmonische Gesellschaft in Laibach, seit dem Jahre ihrer Gründung 1702, bis zu ihren letzten Umgestaltung 1862. Eine $^{\circ}$ geschichtliche Skizze, «Blätter aus Krain, 18. oktober, 1862a, 169-70, in v posebnem odtisu Friedrich Keesbacher, Die philharmonische Gesellschaft in Laibach seit dem Jahre ibrer Gründung I702 bis zu ibren letzten Umgestaltung 1862. Eine geschichtliche Skizze (Laibach, 1862b), 51-2. 
zabljeno Beethovnovo pismo zahvale za podelitev častnega članstva iz leta I819 ter ob branju privzdignil obrvi. Pozornost je vzbujala mojstrova obljuba, da bo družbi ob priložnosti v zahvalo za imenovanje poslal svoje še neizdano delo. Prepis Šeste simfonije s pripisom »Beethovens Hand mit Röthel « je bil med društvenimi muzikalijami edini vir, ki bi ga veliki mojster utegnil držati v svojih rokah. Čeprav je Keesbacher odstavek o Beethovnovih stikih z Ljubljano sklenil s pomenljivimi besedami - »naj bo kakorkoli že, v vsakem primeru ima družba $v$ dveh $\mathrm{z}$ rdečo napisanih besedah drag spomin na velikega mojstra glasbene umetnosti in ne zamerimo, če si dovoli domnevati, da je na tako časten način prejela eno najpomembnejših Beethovnovih del « -,, je bila misel o najdbi skladbe, ki jo je skladatelj kot zahvalo za častno članstvo poslal glasbenikom v Ljubljano, preveč zamamna, da bi vanjo zares bili želeli dvomiti. ${ }^{6}$

$5 \quad \gg$ Sei dem aber wie ihm wolle, jedenfalls besitzt die Gesellschaft in den 2 mit Rothstift geschriebenen Worten ein liebes Andenken an den Großmeister der Tonkunst und man kann es derselben nicht verargen, wenn sie der Vermuthung Raum gibt, eines der bedeutendsten Werke Beethovens in so ehrender Weise erhalten zu haben. « Keesbacher, »Die philharmonische Gesellschaft in Laibach, « 170 .

6 Keesbacherjevi domnevi so raziskovalci glasbene preteklosti na Slovenskem zadnjih sedemdeset let tako pritrjevali kot nasprotovali. Utemeljitve niso temeljile na oprijemljivih virih, razen v člankih Ivana Klemenčiča, ki se je skliceval na primerjalne raziskave, opravljene $v$ mednarodnem okviru v sedemdesetih in devetdesetih letih prejšnjega stoletja. (Ivan Klemenčič, »Beethovna 6. simfonija in zveze z Ljubljano, « v Zbornik Narodne in univerzitetne knjižnice: $I I$ uredili Branko Berčičc Jože Munda, Maks Veselko in France Vurnik (Ljubljana: NUK, 1978), 9I-9; Ivan Klemenčič, »Šesta simfonija Ludwiga (Ljubljana: NUK, 1978), 9I-9; Ivan Klemenčič, »Sesta simfonija Ludwiga
van Beethovna in njegove zveze z Ljubljano, « Z Zbornik ob jubileju Jožeta Sivvan Beethovna in njegove zveze z Ljubljano, « v Zbornik ob jubileju Jožeta Siv-
ca, uredila Jurij Snoj in Darko Frelih (Ljubljana: Založba ZRC, ZRC SAZU, 2000), i19-30.) Razprava je izšla tudi v angleškem prevodu: Ivan Klemenčič, »The Sixth Symphony by Ludwig van Beethoven and His Connections with Ljubljana, « v Glazbene kulture na Jadranu u razdoblju klasicizma: radovi s medunarodnog muzikološkog skupa održanog u Dubrovniku, Hrvatska, 24.-26.05.20oI = Musical Cultures in the Adriatic Region Ruring the Age of Classicism: Proceedings of the International Musicological Symposium Held in
Partitura, kot jo imamo pred seboj danes, najprepričljivejše priča o svoji nekdanji podobi, spremembah in rabi. Njen format je prečen, $\mathrm{z}$ višino, dolžino in s širino platnice $22 \times 31,5 \times 2,4 \mathrm{~cm}$. Listi merijo približ no $21,3 \times 30 \mathrm{~cm}$. Debelina platnice je $0,3 \mathrm{~cm}$. Hrbet je upognjen, na njem so odtisi treh vezic; vezan je v usnje, prednja in zadnja platnica iz trde lepenke sta prevlečeni z rjavim marmoriranim papirjem. Na prednji platnici je okrasno izrezana nalepka z napisom $\gg \mathrm{N}^{\circ} \mathrm{I}$. «, pri čemer je številka I prečrtana in popravljena $\mathrm{v} \gg 6 \ll$, in dvema okroglima žigoma Filharmonične družbe v Ljubljani (»Philharm. Gesellschaft in Laibach «). Med platnice so uvezani ovoj in IIz folijev v petih sešitkih različnih obsegov, ki sovpadajo s petimi stavki simfonije. Knjižni blok je šivan z nitjo skozi hrbet. Obreza je brizgana z modrim pikčastim obrizgom. Vezava je bila v novejšem času delno restavrirana (verjetno ob razstavi v NUK leta 1967 ali 1970). Dodana ali zamenjana sta bila kapitelni trak in kapitel ter nalepljena nova vezna lista. Med ovoj in naslovnico ter med strani 76 $77,98-99$, I $84-185$ je bil vlepljen prosojni japonski papir. Strani so bile oštevilčene arhivsko na recto oziroma neparnih straneh ter na zadnji popisani strani, verjetno ob inventarizaciji in bibliografski obdelavi v knjižnici. V rokopisu ni sledi starejše paginacije.

Prisotnih je več vrst mehansko rastriranega notnega papirja. Prvi trije stavki so pisani na dvanajstsistemskem papirju. Crtovja so visoka približno $0,75 \mathrm{~cm}$ in dolga približno $25,7 \mathrm{~cm}$. Razdalja med najvišjo črto prvega in najnižjo črto zadnjega črtovja meri $18,5 \mathrm{~cm}$. Vodni znak je šesterokraka morska zvezda (višina in širina 2,8 cm) nad črkami EGA (širina $8,5 \mathrm{~cm}$ ) in polmesec z obrazom (širina $3,2 \mathrm{~cm}$ ). ${ }^{7}$ Že na otip se razlikuje prvi in zadnji list tretjega stavka z odtisom treh polmesecev (širina približno $9 \mathrm{~cm}$ ) in črk GFA (širina $6,5 \mathrm{~cm}$ ). Četrti in peti stavek sta napisana na štirinajstsistemskem papirju. Črtovja četrtega stavka so visoka približno $0,7 \mathrm{~cm}$ in dolga približno $25,7 \mathrm{~cm}$. Razdalja med najvišjo črto

Dubrovnik, Croatia, on May 24-26, 20oI, uredila Vjera Katalinić in Stanislav Tuksar (Zagreb: Hrvatsko muzikološko društvo, 2004), IO5-19.

7 Pole papirja so prerezane sredi vodnih znakov, zato višine ni bilo mogoče izmeriti. 


\begin{tabular}{|c|c|c|c|c|}
\hline Fol. & Str. & Vsebina & Papir & Vodni znak \\
\hline Ir & I & naslovnica & \multirow{4}{*}{ I2-vrstični } & \multirow{4}{*}{$\begin{array}{l}\text { morska zvezda - EGA - polmesec z obrazom } \\
\text { (r. list 3. stavka: trije polmeseci - GFA) }\end{array}$} \\
\hline $\mathrm{IV}-38 \mathrm{v}$ & $2-76$ & I. stavek & & \\
\hline $39 r-55 v$ & $77-110$ & 2. stavek & & \\
\hline $56 \mathrm{r}-8 \mathrm{ov}$ & III-I60 & 3. stavek & & \\
\hline $8 \mathrm{Ir}-92 \mathrm{~V}$ & $\mathrm{I} 6 \mathrm{I}-\mathrm{I} 84$ & 4. stavek & I4-vrstični & IF - trije polmeseci \\
\hline $93 \mathrm{r}-113 \mathrm{~V}$ & $185-226$ & 5. stavek & I4-vrstični & orel z dvignjenimi krili - GFA - trije polmeseci \\
\hline
\end{tabular}

prvega in najnižjo zadnjega črtovja meri $18,6 \mathrm{~cm}$. Vodni znak na papirju sta črki IF in trije polmeseci (širina približno II cm). Vodni znak na papirju petega stavka je orel z dvignjenimi krili (širina $5,5 \mathrm{~cm}$ ) nad črkami GFA (širina $6,5 \mathrm{~cm}$ ) in trije polmeseci (širina približno $8,5 \mathrm{~cm}$ ). Črtovja so visoka približno $0,65 \mathrm{~cm}$ in dolga približno $25,7 \mathrm{~cm}$. Razdalja med najvišjo črto prvega in najnižjo zadnjega črtovja meri $19,3 \mathrm{~cm}$.

Vtisi v papir kažejo, da so bile pole papirja zgibane horizontalno in vertikalno ter prerezane po daljšem pregibu. Tako dobljeni prepognjeni listi ali bifoliji v prečnem formatu so bili zloženi drug v drugega glede na predvideno število strani za prepis celega stavka. Odstopanja kažejo na spremembe $\mathrm{v}$ procesu prepisovanja ali na kasnejše zamenjave.

Prvi stavek obsega I9 prepognjenih listov, sešitih po sredinskem pregibu s štirimi neenakomerno dolgimi šivi. Vidne so sledi starejše perforacije (pet vbodov na razdaljah približno $3,5 \mathrm{~cm}$ med prvim in drugim ter približno $5,5 \mathrm{~cm}$ med naslednjimi tremi). Drugi stavek obsega 8 prepognjenih listov, sešitih po sredini hrbta. Med 6. in 7. listom je na levi strani všit dodaten folij. Dolžine šivov in sledi perforacije so enake oziroma v istih razmerjih kot v prvem stavku. $V$ tretjem stavku so listi zloženi veliko kompleksneje kot pri predhodnih. V dva zunanja bifolija sta vložena dva svežnja listov s petimi oziroma štirimi prepognjenimi listi, za njima je vlepljen še en prepognjen list. Oba svežnja sta sešita s štirimi neenakomerno dolgimi šivi. Med tretji in četrti list drugega svežnja je na levi všit

dodaten folij. Sledi prvotne perforacije so vidne v drugem svežnju. Peti stavek obsega io prepognjenih listov, sešitih po sredini hrbta s štirimi šivi. Med drugi in tretji list je na desni strani všit dodatni folij (del vodnega znaka z lilijo kaže na enako vrsto papirja, kot je bila uporabljena v zadnjih dveh stavkih Beethovnovega avtografa). ${ }^{8} \mathrm{Na}$ desnih folijih so vidni trije vbodi, oddaljeni drug od drugega približno $5,5 \mathrm{~cm}$. Četrti stavek obsega 6 prepognjenih listov, sešitih po sredini s štirimi temnejšimi šivi ter od polovice še z daljšim svetlejšim šivom. Na straneh 165 in 168 so manjši delčki, prelepljeni z rastriranim papirjem in korigirani.

$\mathrm{V}$ desnem spodnjem kotu zadnjih folijev drugega, tretjega in petega stavka je vidna kopistova zabeležka obsega oziroma količina porabljenih listov, ki se ujema s številom listov v sešitku (2. stavek: 8 1⁄2: 3. stavek: nečitljivo; 5 . stavek: $\gg 101 / 2 \ll)$.

Način zlaganja papirja, sledi vbodov ter porumenelost zunanjih strani ovojnih listov posameznih stavkov dokazujejo, da partitura prvotno ni bila zvezana v celoto, ampak v ločene sešitke. Predvsem strani I (naslovnica), 77 (začetek 2. stavka) in 185 (začetek 5. stavka) pričajo o intenzivnejši izpostavljenosti svetlobi in drugim vplivom okolja kot sosednje notranje strani, spodnje strani prepognjenih listov pa so tudi bolj

8 Sieghard Brandenburg, »Kommentar, « v Ludwig van Beethoven. Sechste Symphonie F-Dur, Opus 68: Sinfonia pastorale. Faksimile nach dem Autograph BH 64 im Beethoven-Haus Bonn (Bonn: Beethoven-Haus, 2000a), 10, I2-3. 
umazane. Izjema je četrti stavek, na katerem razen sledov listanja na zunanjih spodnjih vogalih strani, ki so sicer prisotne v celotni partituri, ni opaznih izrazitejših vplivov okolja.

Rokopis je pisan s črnilom z roko Beethovnovega kopista Klumparja, razen četrtega stavka, ki ga je napisal doslej neidentificirani prepisovalec oz. zapisovalec. Na več mestih so vidna dopolnila oziroma popravki z grafitnim svinčnikom, na dveh mestih pa tudi z rdečo kredo (Röthel). Poleg pisave glavnega prepisovalca so tako na ovoju in naslovnici kot $\mathrm{v}$ notnem zapisu prisotne poteze drugih rok.

$\mathrm{Na}$ uvezanem ovoju je $\mathrm{z}$ neidentificirano starejšo pisavo napisano: »Symphonie pastorale «. Naslov je obrobljen s tanko okrasno vijugo, pod njim je naveden skladatelj: »Beethoven «. Nad naslovom je dvakrat prečrtan ( $s$ poševnimi črticami $\mathrm{v}$ desno in levo stran), a razločno viden zapis: »Ouverture «. V isti višini je proti desnemu robu strani zapisana številka $\gg N^{\circ} 6 . \ll$, proti levemu pa žig Filharmonične družbe.

$\mathrm{Na}$ naslovnici je $\mathrm{z}$ močno obledelim rdečim svinčnikom $\mathrm{z}$ latiničnimi črkami napisano »Sinfonia pastorale «. Začetka obeh besed, ki sta zapisani ena pod drugo, sta nekoliko prekrita $\mathrm{z}$ močno potegnjenima, v sredi prekrižanima črtama. Enako prekrižani rdeči črti sta tudi na spodnji polovici strani. Pod zapis je nekdo v nemški pisavi dodal: »Beethovens Hand mit Röthel.« Zadnji vpis na stran je najverjetneje dodal skrbnik društvenega notnega arhiva, ki je na vrhu črtovja zapisal: »Beethovens «, »Sinfonie pastorale «, pod naslov pa še $\gg N^{\circ} 6 . \ll$.

Partitura je urejena po načinu Beethovnovih avtografov tistih let. Godala so zapisana ločeno, in sicer violine in viole na vrhu, violončeli in kontrabasi pa na dnu partiture. V prvem in drugem stavku so $v$ desetih notnih črtovjih drug pod drugim $v$ enakem vrstnem redu kot $\mathrm{v}$ avtografu nanizani parti za prve violine, druge violine (violini), violo (viola), flavti (flauti), oboi (oboe), klarineta (clarinetti), fagota (fagotti), rogova (corni), violončela (violoncelli) in kontrabase (bassi). V drugem stavku igrajo violine s sordino (violini con sordini). V tretjem stavku je zapolnjenih enajst notnih črtovij, saj je Beethoven pred violončela postavil še trobenti (clarini). Partitura petega stavka z vključitvijo dveh pozavn (tromboni), postavljenih pred trobenti, obsega trinajst sistemov. Uglasi- tev klarinetov (in $B$ ) je dopisana v prvem stavku, rogov (in $B) \mathrm{v}$ drugem ter trobent (in $C$ ) v tretjem in petem stavku. $\mathrm{V}$ četrtem stavku razporeditev partov $v$ partituri odstopa od avtografa, razlikuje pa se tudi njihovo poimenovanje. $V$ štirinajstih notnih črtovjih so parti za prve violine, druge violine (violini), violo (viola), flavti (flauti), oboi (oboe), klarineta (clarinetti in B), fagota (fagotti), rogova (corny F), pikolo (picolo), pozavni (trombony), trobenti (Trompe in Es), pavke (Timpani in CF), violončela (violoncello) in kontrabase (bassi).

Kopist Klumpar je partituro prepisal neposredno iz avtografa. Dokaz za to so z njegovo roko dodane številke na zgornjem robu Beethovnovega rokopisa, ki se skladajo s sicer neoštevilčenimi stranmi vsakega od stavkov prepisa. Poleg tega niza številk je v avtografu viden tudi še delno zabrisan niz številk, ki se ujema $\mathrm{z}$ razporeditvijo strani kopistovega prvega prepisa partiture. Nedvomno gre za dispozicijo strani pred začetkom prepisovanja, saj so številke postavljene na taktnico zadnjega takta $\mathrm{v}$ obsegu ene strani. Podatek o številu strani je služil pripravi notnega papirja.

V kritičnem poročilu Jensa Dufnerja k izdaji simfonije v Beethovnovih zbranih delih, ki se opira na raziskave primarnih virov, opravljene $\mathrm{v}$ zadnjih desetletjih, so podrobno razčlenjeni posamezne faze v izpisovanju avtografa, prepisovanju partiture in instrumentalnih partov ter skladateljevi posegi v notne zapise. ${ }^{9}$

Primerjalne analize so pokazale, da je kopist iz avtografa prepisoval trikrat. Najprej je, verjetno še pred junijem 1808 , izgotovil instrumentalne parte za že dokončane prve tri stavke simfonije. Poleti i 808 je Beethoven dokončal zadnja dva stavka simfonije in kopist je celotno partituro do srede septembra prepisal za založnika Gottfrieda Christopha Härtla. Po tej predlogi je izdelal tudi parte za zadnja dva stavka. Domnevno so služili za vaje in privatno izvajanje v krogu Beethovnovih mecenov. ${ }^{10} \mathrm{Di}$

9 Dufner, $\gg$ Kritischer Bericht, « 279-87; Brandenburg, »Kommentar, « I828; Jonathan Del Mar, Ludwig van Beethoven. Symphonie Nr. 6 in F-Dur: Pas torale, op. 68. Critical commentary (Kassel etc.: Bärenreiter, 1998), I8-28; Shin Augustinus Kojima, »Probleme im Notentext der Pastoralsymphonie op. 68 von Beethoven, « Beethoven-Jahrbuch 9 (1977): 223-43.

IO Brandenburg, »Kommentar, « 22-3. 
namične oznake in nekatere druge dopolnitve, ki sta jih $\mathrm{v}$ avtograf in prepise partov naknadno vnesla Beethoven ali Klumpar, je v prepis partiture z rdečo kredo zabeležila neidentificirana tuja roka. Beethoven je tako avtograf kot prepis še enkrat pregledal ter korekture in dopolnitve z rdečo kredo zapisoval vzporedno v oba vira, v prepisu pa je popravil tudi nekatere očitne napake in nedoslednosti v dinamičnih označbah. Sredi septembra je založnik Härtel prepisano partituro odnesel v Leipzig in od takrat Beethovnu ni bila več dosegljiva. Dufner ugotavlja, da se začne na tej stopnji razvojna pot simfonije razdvajati, saj Beethoven obeh partitur (avtografa in prepisa), tudi zaradi različne namembnosti, ni uskladil dosledno. Avtograf je ostal merodajen pri Beethovnovem pregledu orkestralnih partov ter za izdelave izvajalske partiture, prepis pa je bil osnova kasnejšega natisa. Šele potem, ko je prepis partiture Beethoven že izročil založniku, je v izvirno partituro vnesel tudi korekture in dodatke iz že preigranih rokopisnih partov. Tokrat je zapisoval s svinčnikom in deloma tudi s črnilom ter vpise praviloma tudi dodatno zaznamoval s križcem na zunanjem robu. Šlo je predvsem za preciziranje dinamike in artikulacije, dopolnjevanje navodil za izvajanje pa tudi za izpisovanje praznih mes in popravljanje napak. Dopolnjeval in popravljal je tudi v obratni smeri.

Drugi prepis oz. izvajalska partitura, ki se danes hrani v Ljubljani, v nasprotju s prvim, ki ga je Beethoven prodal leipziškemu založniku kot tiskarsko predlogo, upošteva vse Beethovnove uskladitve in dodatke iz avtografa, ne pa tudi popravkov, ki jih je Beethoven dodal samo v prvi prepis. Poleg tega se je kopistu pripetilo nekaj napak in nedoslednosti. Pred prvo javno izvedbo je Beethoven korigiral le še prepisano partituro in parte. Zadnjih popravkov v avtograf ni več vpisoval, zato se zdi, da je štel drugi prepis izvirnika za referenčni zapis dela. Na prazno prvo stran je $\mathrm{z}$ rdečo barvo prvič zapisal naslov $\gg$ Sinfonia pastorale «. ${ }^{11}$

II Danes so vse tri rokopisne partiture dostopne na spletu: Sinfonia 6ta, avtograf, [1808], Beethoven-Haus Bonn, BH 64, in 6ta Sinfonia Pastorella, avtorizirani prepis, [1808], Beethoven-Haus Bonn, NE I46 v Digitales Archiv na rizirani prepis, [I808], Beethoven-Haus Bonn, NE I46 v Digitales Archiv na
naslovu http://www.beethoven.de/de/digitales-archiv; Sinfonia pastorale, avtorizirani prepis, [1808]. Narodna in univerzitetna knjižnica, Ljubljana, Glas-
Poleg naslova je $\mathbf{v}$ drugem prepisu partiture še približno deset Beethovnovih lastnoročnih popravkov in dodatkov s svinčnikom. $V$ drugem stavku je spremenil instrumentacijo basovske linije tako, da je igranje parta violončel omejil na dva solista, preostali pa igrajo skupaj s kontrabasi. Spremembe v avtograf ni zabeležil, jo je pa 28. marca I809 sporočil založniku v pismu, kateremu je priložil danes žal izgubljeni korekturni seznam. ${ }^{12} \mathrm{Na}-$ vodilo je bilov part violončela izvirne izdaje instrumentalnih partov dodano kot opomba na dnu strani (Due Violoncelli Solo $I^{m o}$ e II ${ }^{d o}$ con Sordino gli Violoncelli Tutti coi Bassi). Takte od 20 do I22 (od strani 8I do I06) je Beethoven pod partituro oštevilčil. Domneva se, da se številčenje navezuje na pripravo izgubljenega korekturnega seznama za založnika, saj je popravkov znotraj teh taktov največ. ${ }^{13} \mathrm{~V}$ partih flavte in oboe je na štirih mestih popravil noto ter dodal znak za artikulacijo. Oznake za staccato v partu violine na strani 89 so edini dodatek z rdečo barvo, za katerega se predpostavlja, da jih je skladatelj dopisal na vajah pred koncertom. ${ }^{14} \mathrm{Na}$ strani 99 je pod partituro skicirano opozorilo kopistu za I. flavto. Gre za podoben način beleženja idej, kot ga je najti v avtografu. Poleg popravkov v notah je Beethoven $\mathrm{v}$ drugem in $\mathrm{v}$ petem stavku spremenil začetno oznako tempa.

Čeprav so v partituri Beethovnove korekture zabeležene s svinčnikom, pa niso vsi dodatki s svinčnikom Beethovnovi. Na koncu tretjega stavka (str. I60) je pod črtovjem dopisan znak $\gg \Theta \ll$, katerega pomena iz partiture ne moremo razbrati. $V$ štirih stavkih so nad partituro dopisane orientacijske črke oziroma črke »za vajo « (I. stavek: B-G, 2. stavek: B-F, 4. stavek: B-C, 5. stavek: D-G). Opazimo lahko tudi popravke bolj ali manj očitnih napak s črnilom v svetlejši rjavi barvi.

bena zbirka, M tre Beethoven (Inv. št. MZ 1765/1955) v Digitalni knjižnici Slovenije na naslovu http://www.dlib.si.

$12 \gg$... bey Andante in derselbigen Sinf. Ist noch anzumerken in der Baßstimme: gleich anfangs: due Violoncello Solo Imo e 2 do con Sordino gli Violoncelli tutti coi Bassi «. Sieghard Brandenburg, ur., Ludwig van Beethoven - Briefwechsel Gesamtausgabe, 2 (München: G. Henle, 1996), 53-4.

13 Klemenčič, »Šesta simfonija Ludwiga, « I22; Dufner, »Kritischer Bericht, « 278.

I4 Del Mar, Ludwig van Beethoven, 39. 
264 Beethovnovi lastnoročni popravki in dodatki s svinčnikom 2. stavek

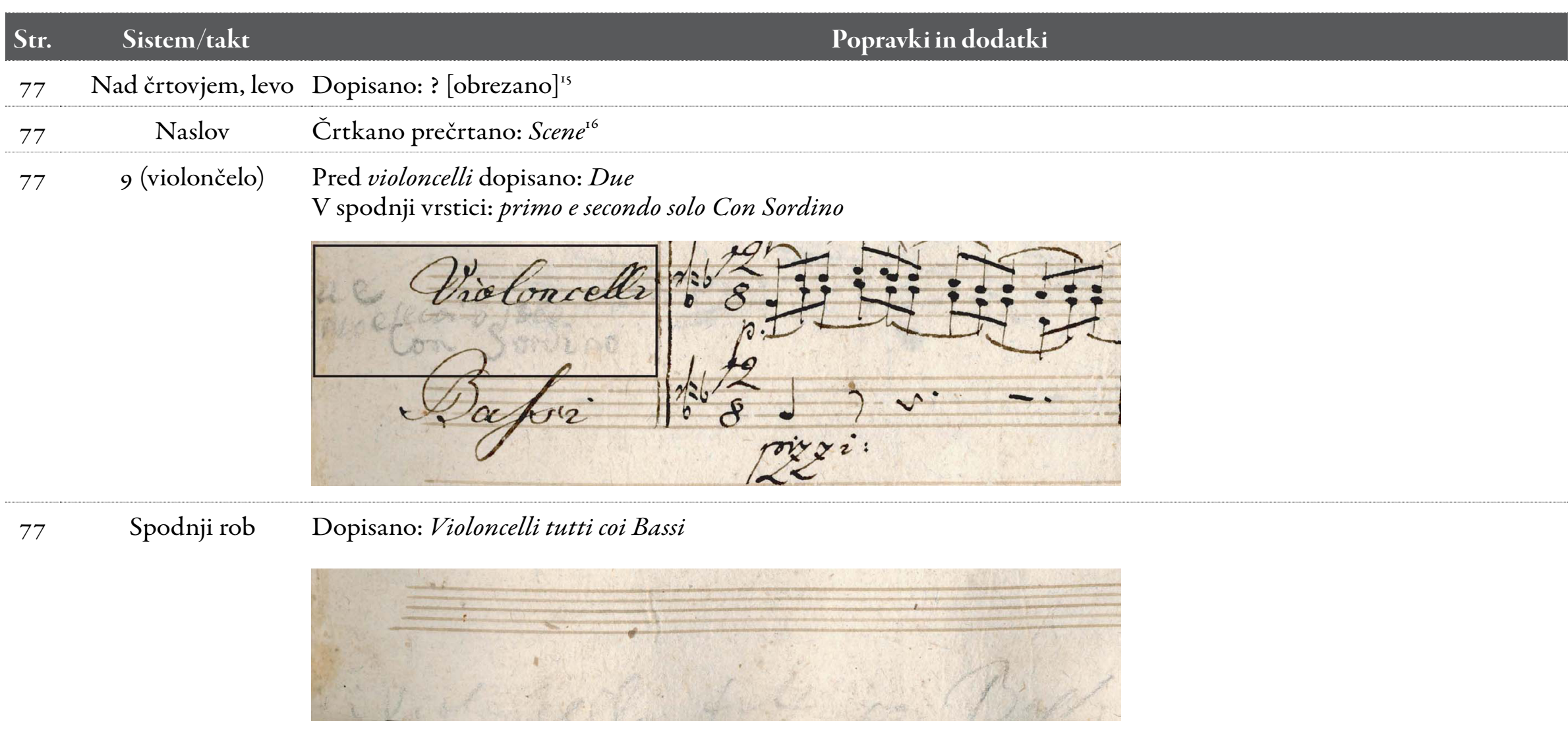

I5 Del Mar je po spodnji vijugi s svinčnikom sklepal, da bi bila popravljena oznaka tempa lahko »quasi allegro « (Del Mar, Ludwig van Beethoven, 35). I6 Verjetno zgolj korekcija kopistovega prepisa. 


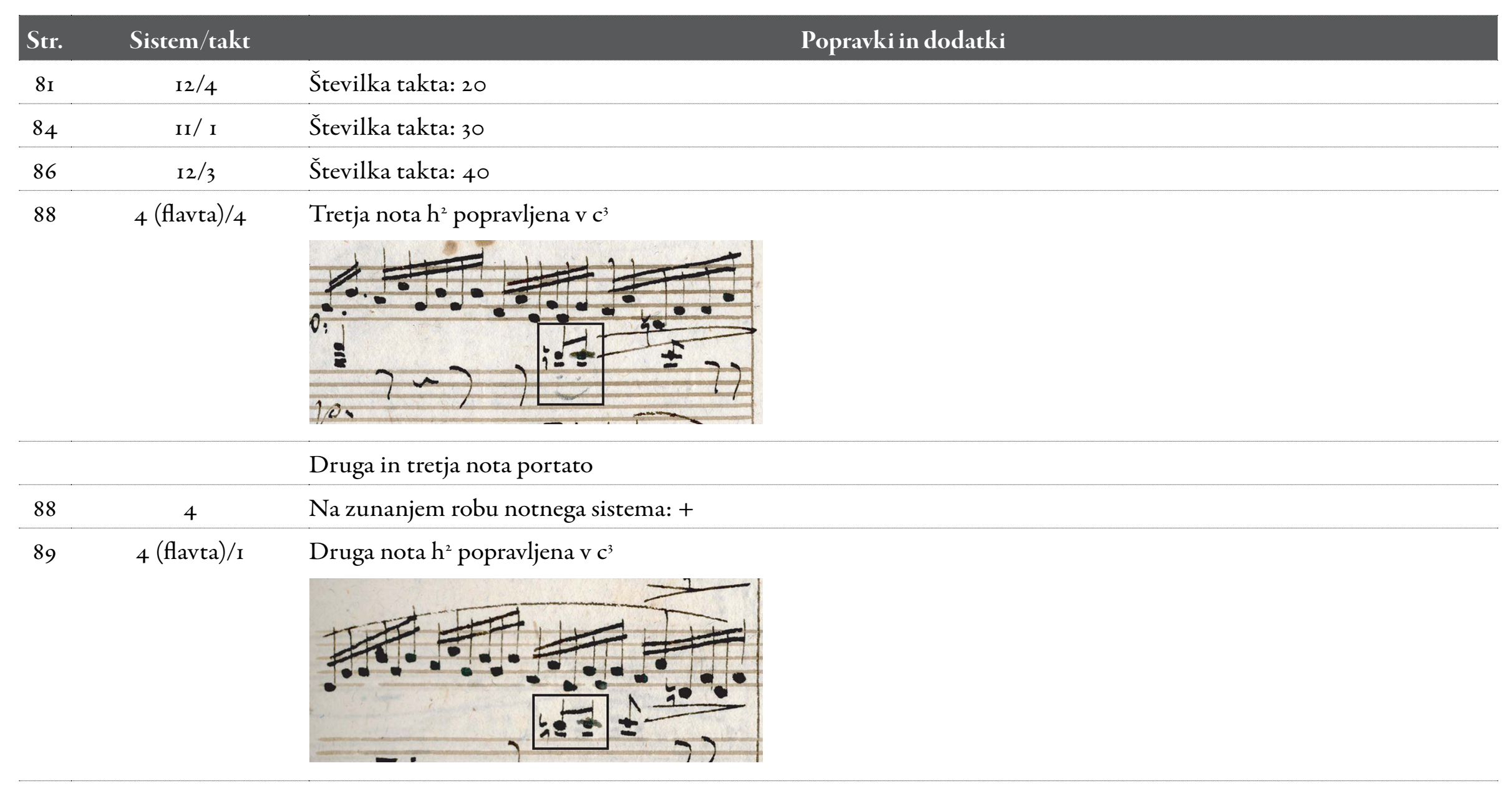




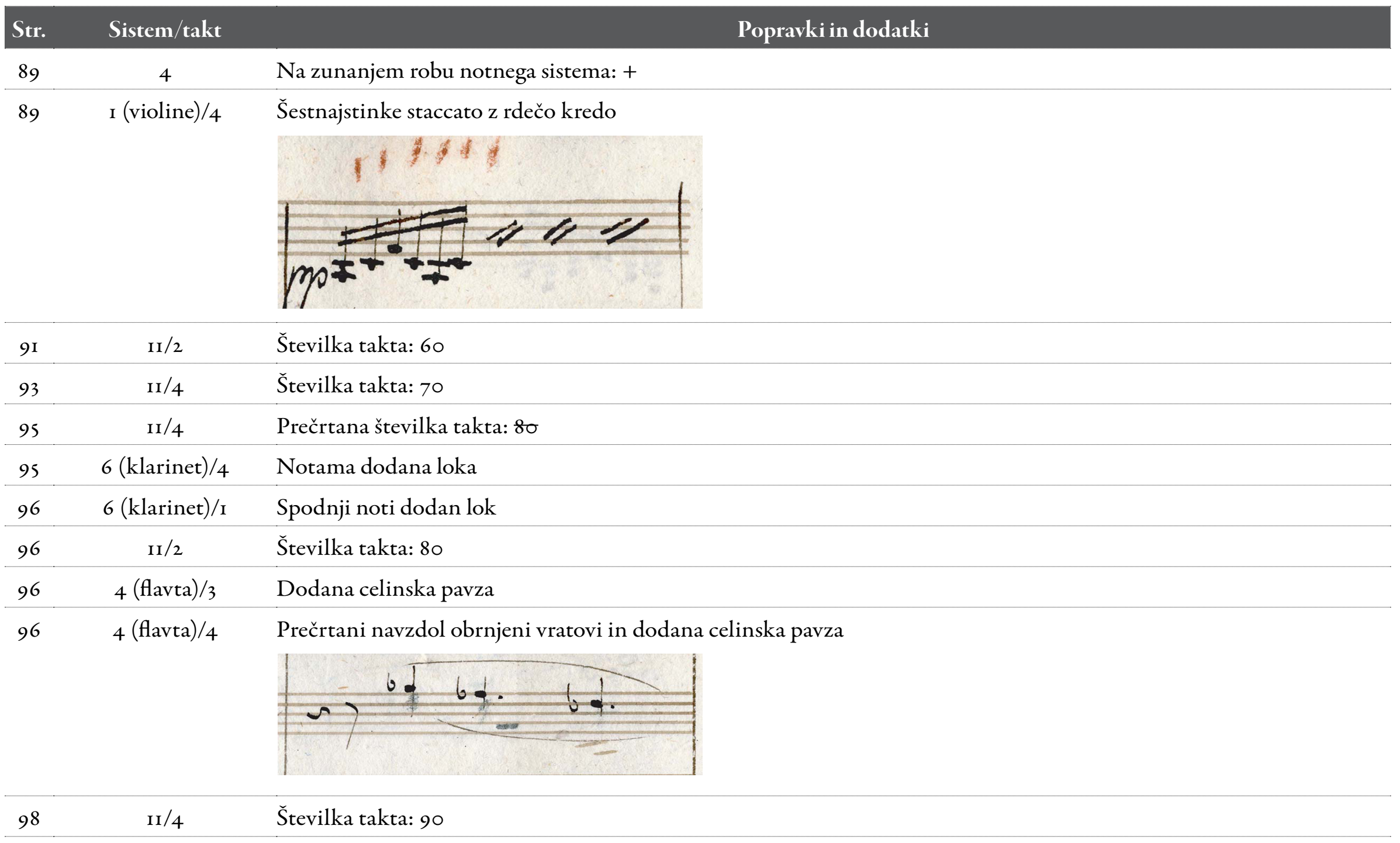




\section{Str. Sistem $/$ takt}

Popravki in dodatki

$99 \quad$ I2/I-4 Melodija prve flavte zapisana oktavo nižje

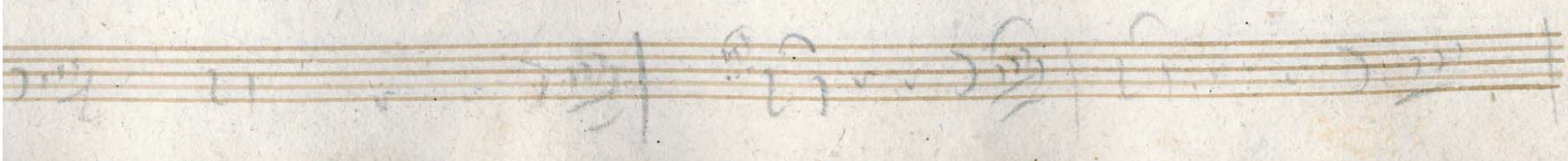

\begin{tabular}{lcll} 
IOI & II/2 & Številka takta: IOO \\
\hline IO3 & II/4 & Številka takta: IO \\
\hline I06 & $5($ oboa $) / 4$ & Tretja nota $\mathrm{e}^{2}$ popravljena $\mathrm{vf}$ \\
& &
\end{tabular}

Druga in treta nota portato

$\begin{array}{lcll}\text { I06 } & 5 & \text { Na zunanjem robu notnega sistema: + } \\ \text { I06 } & \text { I2/4 } & \text { Številka takta: } 22 \\ 107 & 5(\text { oboa }) / \mathrm{I} & \text { Tretja nota } \mathrm{e}^{2} \text { popravljena } \mathrm{f} \mathrm{f}^{2} \\ & & & \end{array}$

$107 \quad 5 \quad$ Na zunanjem robu notnega sistema: +

IO9 4 (flavta) $/ 5 \quad$ Prvi noti dodan lok 
5. stavek

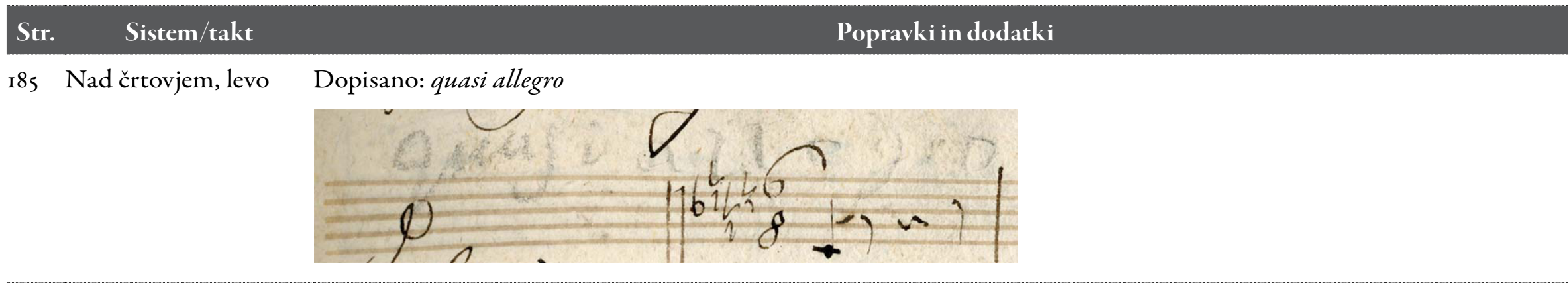

I85 I2 (violončelo)/5-6 Notama dodana loka, svinčnik ${ }^{17}$

\section{Drugi popravki in dodatki}

\begin{tabular}{|c|c|c|}
\hline Str. & Sistem/takt & Popravki in dodatki \\
\hline 2 & Naslov & Beseda Rückunft v Ankunft, črnilo \\
\hline 29 & I (violine)/4 & Četrti noti dodan višaj, črnilo \\
\hline 34 & $7($ fagot $) / \mathbf{I}$ & Zgornji noti dodan višaj, višaj spodnje note prečrtan, črnilo \\
\hline 67 & Io (violončelo)/4 & Zadnji noti dodan lok, črnilo \\
\hline 83 & 6 (klarinet)/4 & Prvi spodnji noti dodan višaj, črnilo \\
\hline 86 & $6($ klarinet $) / 3$ & Nad prvi noti dopisano: g, črnilo \\
\hline III & Naslov & Beseda Zusammensein v Zusammenseyn, črnilo \\
\hline IIs & I (violina) $/ 5$ & Druga nota $\mathrm{f}^{\mathrm{i}}$ popravljena $\mathrm{v} \mathrm{g}^{\mathrm{I}}$, svinčnik \\
\hline 160 & II $/$ IO & Dopisano: $\Theta$, svinčnik \\
\hline
\end{tabular}

17 Loka sta verjetno dodana pomotoma (Del Mar, Ludwig van Beethoven, 55). 
Svoje napake je kopist popravljal na prav poseben način. Da mu ni bilo treba sproti odlagati namočenega peresa, si je mesto z napako ob robu strani označil s kratko poševno črtico in jo popravil kasneje. $V$ partituri so vidne sledi brisanja, pa tudi popravljena mesta, ki jih ni označil ob robu vrstice (npr. str. 6I). Prva poševna črtica je na strani 5 , v štirih stavkih pa jih je skupaj 45 .

Četrti stavek simfonije ni izvirni Klumparjev prepis. Ugotovljeno je bilo, da je bil spartiran po izvirni izdaji partov. ${ }^{18}$ Število strani v prepisu se sicer ujema z zadnjo naznačeno stranjo $v$ Beethovnovem avtografu, vendar je razporeditev taktov po straneh $\mathrm{v}$ prepisu drugačna. Spremenjeno je tudi zapovrstje partov v partituri. V avtografu je pikolo umeščen pod part flavt, part pozavn pa postavljen na dno partiture. $\mathrm{V}$ prepisu so parti vseh štirih glasbil, ki ne igrajo v prvih dveh stavkih, vstavljeni med parta rogov in violončel v zaporedju pikolo, pozavne, trobente in pavke. Prav tako je v prepisu stavek naslovljen Gewitter, Sturm in ne »Donner, Sturm «, kot je zapisano v avtografu. V partu trobent za razliko od poimenovanja $\mathrm{v}$ izvirniku in drugih stavkih prepisa (clarini) piše Trompe. Prepisovalec se je pri svojem delu kar nekajkrat zmotil in takte enostavno prečrtal (str. 163), popravil, brez da bi si vrstico z napako posebej označil (npr. str. 167, 171, 175), ali pa celo prelepil (str. 165 in 168 ).

Ob vezavi je bil knjižni blok obrezan v živi rob, zato se je poravnava na zgornjem robu spustila do zapisa. Na številnih straneh so odrezani zgornji deli lokov, ${ }^{19}$ zareze pa so poškodovale tudi oznake tempov in predvsem naslove stavkov. Delno ali povsem odrezane besede so v nadaljevanju rekonstruirane primerjalno $\mathrm{z}$ avtografom in prvim prepisom partiture. Žal je bil tudi slednji znatno poškodovan ob vezavi, dodatno pa še z izlitjem vode.

I8 Kojima, »Probleme im Notentext der Pastoralsymphonie,«234; Dufner, $\gg$ Kritischer Bericht, « 277.

I9 Poškodovane so strani 18, 54, 115, 193-195, 212, 216-217, 219, 224, 226

I. stavek

\section{Str. Vidno in delno odrezano besedilo \\ Rekonstruirano besedilo}
2 Allõ ma non troppo Angenehme beitre Empfindungen welche bey der Ankunft auf dem / Lande im Menschen erwachen
All[ egr $]$ o ma non troppo
Angenehme heitre
Empfindungen welche bey der Ankunft auf dem Lande im Menschen erwachen

\section{2. stavek}

\begin{tabular}{|c|c|}
\hline Vidno besedilo & \\
\hline $77 \quad[\ldots]$ & [Andante molto moto] \\
\hline fcene [prečrtano] am Bach & Scene am Bach \\
\hline 3. stavek & \\
\hline Vidno besedilo & \\
\hline in Allo: & All[egro]: \\
\hline Lustiges Zusammenseyn der [...] & $\begin{array}{l}\text { Lustiges Zusammenseyn } \\
\text { der [Landleute }]\end{array}$ \\
\hline I29 a tempo & A tempo [allegro] \\
\hline I57 a tempo allo & A tempo all $[\mathrm{egr}]_{\mathrm{o}}$ \\
\hline
\end{tabular}




\section{5. stavek}

\section{Str.}

\section{Vidno besedilo}

Rekonstruirano besedilo

I85 [...]

[...]

[...] / nach dem Sturm

\section{$[\text { Allegretto }]^{20}$}

[Wohltätige, mit Dank an die Gottheit verbundene Gefüble] nach dem Sturm

Vrnimo se h Keesbacherju in njegovemu opisu partiture iz leta 1862. Beethovnovo pisavo je poleg naslova, napisanega $\mathrm{z}$ rdečo kredo, prepoznal še v dveh korekturnih vpisih s svinčnikom. Citiral je zapis na spodnjem robu prve strani drugega stavka ter pripis »quasi allegro « pod oznako tempa $\gg$ Allegretto $\ll$ na začetku petega stavka. ${ }^{21}$ Oznaka tempa in naslov petega stavka, ki ju navaja Keesbacher, danes nista več vidna, ker sta bila pri vezavi domala popolnoma odrezana.

20 Del Mar je iz spodnjega roba pisave razbral besede Hirtengesang Allegretto (Del Mar, Ludwig van Beethoven, $\mathrm{xx}$ ).

21 I Diese Partitur zeigt an mehreren Stellen Korrekturen in Bleistift ausgeführt. Zwei davon scheinen von Beethovens Hand zu stammen; leider ist das Blei schon verwischt, das an eine endgültige Entscheidung über die Schriftzüge schwer zu denken ist. In der Szene am Bach, wo der I2/8 Takt begint (aus b dur) stehen die Worte: »Violoncelli tutti con Basso《. Namentlich das B erinnert an die Beethoven'sche Schreibart. Ferner die Tempo-Vorzeichnung beim Beginne des Hirtengesanges (in f, 6/8 Takt, Allegretto ist von derselben Hand in Bleistift näher bestimmt mit den nachfolgenden Worten: ,quasi allegro. Ein direkter Beweis der Uebersendung liegt nicht vor. « Keesbacher, »Die philharmonische Gesellder Uebersendung liegt nicht
schaft in Laibach, « 170.
Keesbacher pred seboj torej ni imel partiture v današnji vezavi. Nenavadno je tudi, da je pri opisovanju naslovnico poimenoval ovoj. ${ }^{22}$ Prav tako porezane so orientacijske črke nad notnim zapisom in očitno je, da so bile v partituro vpisane pred zadnjo vezavo.

Označitev petih stavkov simfonije s tremi nizi črk oziroma delitev skladbe na tri stavke se sklada $\mathrm{z}$ navedbami v sicer nepopolno ohranjenih sporedih filharmoničnih koncertov (akademij) od leta I822 do I83I. Zadnje tri stavke, ki jih je Beethoven povezal z oznako attacca, so igrali kot enoten 3. stavek. V dveh sporedih iz let I 823 in I825 so naslov $\mathrm{Pa}$ storal Sinfonie oder Erinnerung an das Landleben in programski naslovi stavkov navedeni v izpiljeni različici prve izdaje orkestralnih partov iz leta I809. ${ }^{23}$ Podatek dopušča sklepanje, da so ljubljanski filharmoniki iz njih igrali že leta I8ı8, ko je bila simfonija prvič dokumentirano izvedena v Ljubljani, ${ }^{24}$ pa tudi, da so bili kasneje predloga za spartiranje v partituri manjkajočega snopiča z zapisom 4 . stavka.

22 Keesbacher (»Die philharmonische Gesellschaft in Laibach,« 170) pravi: $\gg$ Das gedachte Exemplar ist eine (nicht von ihm) geschriebene Partitur. Auf dem Umschlage steht mit Rothstift und zwar unverkennbar in seinen Charakteren geschrieben: ,Sinfonie pastorale, darunter stehen mit Tinte von anderer Hand geschrieben die Worte: ,Beethovens Hand mit Röthel':«

23 Naslovi stavkov v koncertnem listu z dne 23. 5. I823 so: » Erster Satz: Erwachen heiterer Empfindungen bey der Ankunft auf dem Lande, Zweyter Satz: Scene am Bach, Dritter Satz: Lustiges Zusammentreffen der Landleute Gewitter, Sturm - Hirtengesang. Frohe und dankbare Gefühle nach dem Sturme.« Arhiv Filharmonične družbe, Koncertni sporedi, Narodna in univerzitetna knjižnica, Ljubljana, Glasbena zbirka. Prim. part prve violine v prvi izdaji iz leta 809 . Beethoven, Ludwig van, Sinfonie Pastorale pour a Violons, 2 Violes, Violoncelle et Contre-Violon, 2 Flûtes, petite Flûte, 2 Hautbois, 2 Clarinettes, 2 Bassons, 2 Cors, 2 Trompettes, Timbales et 2 Trompes, parti. Leipzig: Breitkopf \& Härtel [1809], št. plošče 1337. Dostopno na: Beethoven-Haus Bonn, Digitales Archiv, www.beethoven.de/de/digitales-archiv.

$24 \mathrm{~V}$ literaturi se kot datum prve izvedbe navaja 28. 2. 1818, povzet po koncertnem sporedu iz arhiva Filharmonične družbe, ki je danes izgubljen. Podatek je v rokopisni kroniki Filharmonične družbe zabeležil tudi Keesbacher (Die philharmonische Gesellschaft in Laibach, Io8). Da so na akademiji Filharmonične družbe pastoralno simfonijo (»die herrliche Pastoralsymphonie«) igra- 
Filharmonična družba je partituro izdatno ožigosala, žal pa njenega prejema ni zabeležila. Nekaj časa je služila praktičnim izvajalskim namenom in zdi se, da ji do prihoda Keesbacherja niso posvečali posebne pozornosti. In če so pred davnimi dvesto leti ob izvolitvi Beethovna za častnega člana Filharmonične družbe prejem njegovega pisma takoj naznanili v časopisu, je molk ob domnevnem prejemu tako razkošnega darila toliko nedoumljivejši. ${ }^{25}$

Glasbena zbirka NUK je partituro prevzela od Akademije za glasbo v Ljubljani 28. junija 1955. Akademija je v povojnih letih delovala $\mathrm{v}$ konfiscirani zgradbi Glasbene matice in razpolagala tudi z njeno bogato knjižnico. Tri desetletja prej je podobna usoda doletela zbirko muzikalij Filharmonične družbe, ki je po prvi svetovni vojni postala podružnica Glasbene matice. V prevzemnem dokumentu je pod točko 23 navedeno: »Beethoven, Symphonie pastorale, orkestralna partitura, starinski prepis. $\ll^{26} \mathrm{~V}$ inventarno knjigo zbirke za leto 1955 je bila vpisana pod številko $1765 .{ }^{27}$

li pred aprilom I8I9, potrjuje tudi poročilo $\gg$ Aus der Tagsgeschichte von Laibach, «Illyrisches Blatt, 30. april, I819, 70.

$25 \gg$ Ludwig van Beethoven, «Illyrisches Blatt, 28. maj, I819, 85.

26 Prevzemni dokument je za NUK podpisal Ludvik Zepič. V poslovnem poročilu o letu I955 za Glasbeni oddelek NUK je zabeleženo, da je »NUK odstopila zaradi zamenjave iz svoje FZC-zaloge Akademiji za glasbo v Ljubljani okrog 800 antikvaričnih, po večini nemških šolskih teoretičnih muzikalij, prejela pa za to za NUK mnogo pomembnejšo tvarino in sicer muzikalije iz dragocenega arhiva ljubljanske Glasbene matice, to je nad rooo slovenskije izodropi kopishih skladb starejsih slovenskih sklja vinsko važnih društvenih spisov bivše ljubljanske Filharmonične družbe. Vse to gradivo je po letu osvoboditve (1945) hranila v svoji knjižnici Akademija za glasbo, zdaj pa ga je odstopila v zamenjavo NUK-i.«

27 Datum prejema: 28. VI. 1955, datum vpisa: 29. VI., naslov dela: Beethoven L.: Symphonie pastorale, orkestr. partitura, izv. prep., način nabave: $Z$, dobavitelj: Akademija za glasbo, Ljubljana, Opombe: Arhiv Glasbene matice v Ljubljani. Iz delovne statistike za mesec junij 1955 je razvidno, da je bil kataložni listek za abecedni-imenski katalog izdelan 29. 6. 1955. 